\title{
Traditions \& Customs of Ancient Indian Culture and Their Role in COVID 19 Pandemic Prevention and Control
}

\author{
Abhishek Tiwari ${ }^{1}$, Manish Kumar Manar ${ }^{2}$, Shivendra Kumar Singh ${ }^{3}$, Udit Mohan ${ }^{4}$, Kanchan Panday ${ }^{5}$, Uday $^{2}$
} Mohan $^{6}$

${ }^{1}$ Post MD PhD Scholar, Department of Community Medicine \& Public Health, King George's Medical University, Lucknow, Uttar Pradesh; ${ }^{2}$ Associate Professor, Department of Community Medicine \& Public Health, King George's Medical University, Lucknow, Uttar Pradesh; ${ }^{3}$ Professor, Department of Community Medicine \& Public Health, King George's Medical University, Lucknow, Uttar Pradesh; ${ }^{4}$ Consultant-Program Coordinator, Johns Hopkins Bloomberg School of Public Health, Department of International Health, Health Systems Program, Lucknow, Uttar Pradesh, India; ${ }^{5}$ Resident, Department of Community Medicine, Motilal Nehru Medical College, Prayagraj, Uttar Pradesh; ${ }^{6}$ Professor \& Head, Department of Community Medicine, Era's Lucknow Medical College \& Hospital, Lucknow, Uttar Pradesh

\begin{tabular}{|c|c|c|c|c|c|c|c|}
\hline Abstract & Introduction & Methodology & Results & Conclusion & References & Citation & Tables/ Figures \\
\hline
\end{tabular}

\section{Corresponding Author}

Dr. Manish Kumar Manar, Associate Professor, Department of Community Medicine \& Public Health, King George's Medical University, Lucknow, Uttar Pradesh, 226003

E Mail ID: manar.781@gmail.com

\section{Citation}

Tiwari A, Manar MK, Singh SK, Mohan U, Panday K, Mohan U. Traditions \& Customs of Ancient Indian Culture and Their Role in COVID 19 Pandemic Prevention and Control. Indian J Comm Health. 2020;32(2):317 - 323.

Source of Funding: Nil Conflict of Interest: None declared

\section{Article Cycle}

Received: 19/05/2020; Revision: 09/06/2020; Accepted: 15/06/2020; Published: 30/06/2020

This work is licensed under a Creative Commons Attribution 4.0 International License.

\section{Abstract}

The truth of COVID 19 Pandemic is that it has already changed the demography of many countries, still changing the Climate \& Environment and will continue to change the Global Economy for quite some time. The simple good personal hygiene and physical distancing measures were identified as one of the most effective protections against COVID 19. The Indian way of living has many scientific principles inherited in it to combat infectious diseases. We follow the Sanatan Sanskriti concepts traditionally, sometimes not even realizing the rationale behind it. This article tries to explore the correlation between the preventive measures and our traditional Sanatan practices. The pandemic has shaken the globe and time has come to rethink and move back to basics of our ancient traditions for a sustainable future. There is a need to promote our cultural practices and avoid running behind the ultra-modern ways of living so that the world learns to combat and live with the COVID 19.

\section{Keywords}

COVID19; Pandemics; Sanatan Sanskriti; Ayurveda; Yoga; Social Distancing; Indian Namaskar

\section{Introduction}

When the globe was heading towards conquering Artificial Intelligence as an inherent tool for virtually doing everything in 2020, the dream line trajectory was deviated by a Virus. Originating from China in December 2019 the novel Corona Virus reached to about 19 Countries by end of January when the WHO declared it a Public Health Emergency of International concern (PHEIC) (1). The prevention and control guidelines were released by the WHO and Ministry of Health \& Family Welfare (MoHFW) Govt. of India $(2,3)$. The simple good personal hygiene measures and physical distancing were declared as most effective protections for the COVID 19(4).
Age old traditions and Customs have been the core of Indian culture. The Indian way of living - Sanatan Sanskriti has many scientific principles inherited in it, to prevent infectious diseases (5). We follow them traditionally sometimes not even realizing the rationale behind it. This article tries to explore the correlation between preventive measures and traditional practices of Sanatan principles of life. These principles were capable of preventing infectious diseases, major killers in ancient times. Many measures are coherent with the Modern Public Health approaches of handling infections and there is a need to realize this reality. 


\section{The Precautionary Measures for preventing COVID 19}

The best way to prevent is to avoid being exposed to the virus as currently there is no vaccine. The social distancing, use of mask, frequent sanitization of hands and avoid touching face and eyes are all aiming to prevent the transmission. COVID-19 virus transmission can occur by direct contact with infected person (Respiratory droplets) and indirect contact with surfaces in immediate environment. Droplet transmission occurs when a person is in close contact (within 6 feet) with infected person. Respiratory droplets produced on coughing, sneezing or talking can land on mouth, nose or eyes of nearby people and infect them. Droplets could also land on surfaces and objects like door handles etc. and can later reach new person on re-touching. Even the asymptomatic persons are capable of infecting others due to viral shredding $(2,3,4)$. The precautionary measures as given by Health Ministry are listed in (Table 1)

\section{Indian Scenario of COVID19}

The first case in India was reported from Kerala on 30th January 2020. The MoHFW in consultation with Ministry of Home affairs, Govt. of India and State Governments, has been tracking the situation and taking strategic actions proactively. When the disease started spreading in different countries, thermal screening and later mandatory quarantine of minimum 14 days for international travellers was implemented by Govt. of India. People were made aware of preventive measures by using all possible means including social, electronic and print media (6).

On call of the Prime Minister, the public voluntarily complied with one day Janta curfew all over India on $22^{\text {nd }}$ March. Thereafter finally our country was put under complete lockdown from $25^{\text {th }}$ March. Importance of Social distancing and hygiene was again emphasized to one and all. The lockdown was extended to second, third and fourth stage but ultimately considering the economical aspect the Unlock began phase wise from $1^{\text {st }}$ June. The number of cases has tremendously increased since then but the recovery rate is the positivity motivating us to keep the fight on.

\section{Role of Customs, Culture \& Traditions of "Sanatan way of life" in Disease Prevention}

India is the most ancient civilization and has its own way of living; the scriptures mention it as Sanatan way of living. It has customs, traditions and culture which define the different code of ethics, behaviour, lifestyle and every aspect of human life. It talks about your daily routine, type of diet, Yoga-asana, and rituals. It is not a religion but rather a way of living. It is based on the tenets of achieving Moksha or salvation and thus restricts to its followers to speak truth and follow the correct path. The Sanatan Sanskriti is above the religion and based on experiences rather than blind teachings. This Sanatan way of living is much ancient to Hinduism, which was the religion being practiced by majority of people in this geographical area.
The principles of Sanatan Sanskriti were central to Hinduism.

The Sanatan Sanskriti, Yoga and Ayurveda are invaluable gift of India's ancient tradition. Sanatan Sanskriti defines how to live a life; Yoga unites mind, body and soul for attainment of physical, mental and spiritual health. Ayurveda deals with preventing diseases and promoting positive health $(7,8)$. All these are known to increase immunity and our defense mechanism essentially needed to fight all diseases including COVID 19. Our lifestyle, behaviour and nutrition are the key factors to fight from diseases. The Sanatan way of living has stressed on these tenets for living a healthy life and numerous scriptures are available in support of that. Sanatan practices have many of the preventive measures essentially required to fight COVID 19. We shall see how these ancient measures are capable of preventing Pandemic and are in coherence with our modern epidemiological and scientific knowledge.

\section{Hand Washing}

The concept of cleanliness ("Shaucha" in Sanskrit") is vital in Sanatan traditions. The cleanliness or purity of anything decides if it is usable or not. The importance given to hand washing, cleaning of body, surroundings and objects to be used is such that your work will be fruitful only if everything is clean. The use of unclean object was rather a $\sin$ in ancient traditions. In Sanatan concepts it is essential to wash hands before eating and performing any ritual. It was also essential to wash hand with water and fly ash or clay or Lona (having detergent properties) after use of Toilets.

To prevent infection there was a concept of separate slippers made of wood, for outdoor and indoor home. Bringing outside slippers inside the rooms and vice-versa was strictly prohibited. People following these rules of Sanatan way of life requests visitors to remove sandal, shoes or slippers outside the house to prevent any probable spread of infection. The description of cleanliness, hygiene and purity are mentioned by Patanjali in Yoga-Sutras, here Shaucha is described as-

शौचात्स्वाङ्गजुगुप्सा परैरसंसर्गः || (2.41)

सत्त्वशुद्धिसौमनस्यैकाग्येन्द्रियजयात्मदर्शनयोग्यत्वानि च।। (2.41)

Shaucha is that from which there arises dislike i.e. dispassion towards one's body and detachment towards contact with others. Shaucha gives rise to purity of mind, contentment, one-pointedness, conquest of the senses and competency to attain Atma-Darshana (SelfRealization).

Manu Smriti also describes Shaucha as one of the four Niyamas or duties (9).

\section{अहिंसा सत्यम् अस्तेयं शौचम् इन्द्रियनिग्रहः |}

एतं सामासिकं धर्मं चातुर्वणर्ये अब्रवीन् मनुः || (10.63)

Non-Violence, Truth, Non-Stealing, Cleanliness/Purity and Sense-Control are the duties that are common for all four 
classes, so declares Manu (10). Hence, Cleanliness is a prime duty as per Sanatan traditions. Violation of cleanliness of body, mind or soul was considered sin. Quite similar to these COVID 19 times where not washing hand is a sin and every celebrity, sportsperson and others are requesting to wash hands with soap or sanitizer regularly. Indian ancient traditions and customs of maintaining cleanliness, hygiene, purity etc. are summarized in (Figure 1).

\section{NO Spitting in Public:}

The Sanatan philosophy further stresses on cleanliness of environment. Atharva Veda mentions the Earth as a Mother, a Living force. The Manu Smriti says that no one should throw filthy substances like urine, faeces, saliva, cloths infected by impure substances, blood and other poisonous things. Thus, our culture also cared at that time regarding water pollution, Soil pollution and Bio Medical Waste. It also stresses about hygienic disposal of faeces and urine and suggested covering them in deep ground with sticks, grass, leaves, clod etc. for natural decomposition. So Sanatan culture was following hygienic practices and environmental friendly methods of waste disposal to sustain healthy life, environment and development much before the world thought of concept of hygiene, waste disposal and sustainable development (11).

\section{Yoga \& Ayurveda}

Yoga uses various postures, breathing exercises, and meditation to improve overall health. Yoga was developed in ancient India as a spiritual practice thousands of years ago. Today, most Westerners do yoga for exercise and to reduce stress. Yoga is one of the best ways available for stress management. It emphasizes unifying mind with body and soul to promote mental, spiritual and physical wellbeing. Vedic literature says one has to clean all the body secretions to avoid various infections and allergies. This includes Nasal mucus secretions, Ear wax, Phlegm, Tears, Rheum of the eyes and Sweat. Even in the times of COVID 19, Yoga will not only improve lung capacity but also stabilize mental health to overcome the stress and depression associated with Pandemic.

Ayurveda originated in India more than 5,000 years ago and is often called the "Mother of All Healing." In Sanskrit it, means "The Science of Life." here emphasis is on prevention and encourages the maintenance of health through close attention to balance in one's life, right thinking, diet, lifestyle and the use of herbs $(12,13,14)$. Ministry of AYUSH (Ayurveda, Yoga and Naturopathy, Unani, Siddha and Homoeopathy) has released self-care guidelines for preventive health measures and boosting immunity with special reference to respiratory health for COVID 19, (15) listed here in (Table 2).

\section{Namaste - The Indian Welcome starts with Namaskar} The Indian way of greeting one another has become global now as it does not require touching or coming close. Many famous international personalities have adopted Indian
Namaskar for greeting others instead of handshake. Now its importance is being realized for implementing the social distancing. Namaskar means "I bow to the divine in you" and is a way of saying 'May our minds meet', indicated by the folded palms placed before the chest. This is an evidence of India's rich cultural heritage being in line modern scientific rationale. (16)

Social Distancing - The Ancient Indian's had Social Stratification

Social distancing is being followed to prevent the spread of Corona Virus. The idea is to avoid being too close to contract the droplets from infected person. Public is advised to stay out of crowded places and avoid going out. (17). But people in essential services like Doctors, health care workers and others - The CORONA Warriors have to go out and are unfortunately getting infected. The occupational risk of getting infected is highest amongst Doctors and staff of Hospitals. This has given rise to social stigma and some people see these frontline workers as agents of infection. Probably the public has to realize that in this COVID 19 era we have to follow physical distancing but not any kind of hatred with corona warriors as these are the real fighters.

When we look at Ancient Indian system of social stratification i.e. the "Varna Vyayvastha" it was based on occupation or Karma and main principle behind was probably the risk of transmission of infectious agents. As mentioned in Manusmriti, the society was stratified into four categories (varnas) - Brahmins, Kshatriyas, Vaishyas and the Shudras. Brahmins were mainly priests, teachers and intellectuals. Kshatriyas, were the administrator, warriors and rulers, Vaishyas were the artists, farmers, merchants and traders. Shudras were manual labourers. Apart from this there were Dalit or untouchables who were street sweepers and latrine cleaners. (Figure 2) It is understandable that due to different occupational nature of varnas, their risk of transmitting infections were different. The dalits, truly the warriors of keeping public safe, were involved in cleaning of wastes, streets and drains. They definitely had the highest risk of transmitting infection to others while the Brahmins had minimal risk of transmission to other varnas due to their nature of work. Such type of stratification must have been carefully thought and used at those times to prevent spread of infectious diseases from one section to the other. However, unfortunately with time, the work based concept of varna system converted to birth based caste system in the society. Though today the Caste system has many more implications in our society, the original concept of varna system might have been to prevent disease by maintaining the Social Distancing $(18,19,20,21)$.

The present-day Corona Warriors like doctors, nurses, sweepers, police personnel's are facing the same situation. They are important yet being ignored because they are close to the infection. They are doing their duty 
in spite of the risk. In return these warriors are being considered untouchables at many places by the society. We heard house owners trying to vacate their premises from Doctors, Nurses and even Cleaning staff scared from COVID19. These social stigma needs to be addressed seriously and jointly by administration and public because we need these warriors for the victory.(22)

\section{Protection from Mask: Our Traditional Gamchha}

The MoHFW, Govt. of India has recommended use of Mask in public places for protection from COVID19. Earlier its use was limited to those with symptoms and healthcare workers. But expert opinion has changed because of asymptomatic carriers (23). Then queries arose on what type of mask and its availability for 1.3 billion Indians. The homemade mask of cotton cloth was declared to be good enough for the public by MoHFW (24).

Indian gamchha is a traditional thin cotton cloth used very commonly in many rural parts. This works well as a mask considering its availability. Traditionally it is used to dry the body after bathing or wiping sweat and worn on one side of the shoulder. Its appearance and name varies from region to region and is produced as a handicraft. But it serves an excellent purpose of protecting public from contracting disease. It can be easily used by anyone as compared to the surgical mask, which is costly, short of supply and has a specific way to use (25).

Indian Vegetarian food: Sanatan Dharma's Satvik Bhojan Our traditional food is mainly vegetarian; in fact globally India has maximum number of vegetarians. Even in the diverse range of cuisines the basic tenets are the same, use of vegetable, fruits and spices is essential. Mānasollāsa, (The Delight of Mind) written in 12th century describes the need to change cuisine and food with seasons. (26) Utilization of local foods was promoted in Satvik Bhojan for staying healthy and fit.

Indian philosophy of non-violence (ahimsa) keeps us away from animal chain of infective diseases. Rather we have the concept of worshipping animals, as cow is regarded the symbol of fortune and wealth. Non-vegetarian diet is a taboo in Sanatan Sanskriti. This is the best example of disease preventive Indian philosophy. As we all know the suspicious but official origin of this SARS-CoV2 is Animal Market of Wuhan, China.

The relation of food and Health was well known as reflected in this quote from the Bhagavad Gita (27).

"Foods dear to those in the mode of goodness increase the duration of life, purify one's existence and give strength, health, happiness and satisfaction. Such foods are juicy, fatty, wholesome, and pleasing to the heart. Foods that are too bitter, too sour, salty, hot, pungent, dry and burning are dear to those in the mode of passion. Such foods cause distress, misery and disease. Food prepared more than three hours before being eaten, food that is tasteless, decomposed and putrid, and food consisting of remnants and untouchable things is dear to those in the mode of darkness." (Lord Krishna, Bhagavad-Gita 17.8-10) Intake of Vitamin D

We all know that Vitamin D plays a significant role in our immunity system. The studies on COVID 19 are showing that low level of Vitamin $D$ is associated with high mortality especially in elderly population of developed countries (28). Vitamin D supplementation is now recommended to prevent these deaths. Vitamin D synthesis occurs naturally in our skin cells on exposure to sunlight (29). Daily exposure to early morning Sunlight is required. It is advised to get exposure of Sunlight, Sunbath for 30-40 minutes in a week with about $40 \%$ uncovered body (30). The Sanatan Way of living had a concept of offering water to the Sun just after taking bath in the morning in minimal clothes. This early morning exposure to the Sun light if done regularly on seven days serves the modern scientific recommendation. We need to realize the science behind our culture and follow it. $(31,32)$

Disposal of Dead bodies of COVID 19 Patients

The COVID 19 infected bodies have to be treated with utmost precautions and guidelines were issued for the same to avoid spread of infection to person performing last rites. In Sanatan system, dead bodies are cremated by burning to ashes, a complete mechanism of killing or destruction of disease causing agents as compared to the process of burial, which might transmit infection through worms. These worms could be eaten by birds or bat; and might again be eaten by humans to get infected.

In Sanatan system during these rituals the person, who perform last rites, has to discard all his clothes, remove hairs and take bath many times and remain almost in quarantine for at least 13 days. Probably these 13 days compulsory quarantine would have been made equal to the duration of incubation period of infectious deceases.

During this period he has to stay alone, keep physical distancing with other family and community members, and only one person gives him food and other essential things. The Sanatan traditions of removing hair and staying separate were probably to reduce the chance of spreading infection. Thus we understand that Sanatan Cultural practices were scientific, evidence based and quite efficient in prevention of infectious diseases.

\section{Conclusion}

Most of us are today inclined towards modern and advanced culture of the west without even exploring or realizing what all we have in Sanatan Culture. Indian civilization has been one of the most ancient and biggest one. This was the place of learning for scholars all around the world. Sanatan Sanskriti has many preventive measures essentially required to fight COVID 19. Either it be the importance of cleanliness, regular practice of Yoga or utilization of natural medicine in Ayurveda, We have to 
realize the importance of our Traditions and Customs by visualizing it from the scientific lens.

We never thought that we are following physical distancing while bowing for a Namaskar and that the classification of society is probably to prevent disease spread. The pandemic is here to change our behaviour, social structure and also the thought process. The nature has shown us that we were on the right path decades back. Our traditional gamcha, local food and traditional rituals for even the last rites were all coherent with the scientific rationale. There is definite need of more research to create evidence for the hidden scientific underpinnings in favour of our traditional practices so that it is well accepted by the scientific community.

Let not others takeaway the ownership of these customs and traditions like the patent of Neem and Tulsi. Our rich Cultural practices have everything required for our wellbeing, it is time tested. We are now at a junction to decide and move to the correct path. Let the World learn from us how to live with COVID 19.

\section{Recommendation}

Most of the Indian public is aware of the customs, culture and tradition of Sanatan Sanskriti. However their practices have been waning probably due to westernization. Adopting "SANATAN WAY OF LIFE" may be useful in preventing spread of corona virus. There is an urgent need to look back at our ancient practices to deal with the present pandemic.

\section{Relevance of the study}

Traditions, customs and culture of Sanatan Sanskriti are in line with the current modern scientific guidelines issued for prevention of spread of corona virus and we need to realize this.

\section{References}

1. World Health Organization. COVID 19 Public Health Emergency of. (2020) PHEIC, I. C. Global research and innovation forum: towards a research roadmap

2. Ministry of Health and Family welfare, Government of India. Official website. https://www.mohfw.gov.in/ accessed on $02 / 06 / 20$

3. World Health Organization. Modes of transmission of virus causing COVID-19: implications for IPC precaution recommendations. Scientific brief available online at https://www.who.int/newsroom/commentaries/detail/modes-of-transmission-of-viruscausing-covid-19-implications-for-ipc-precautionrecommendations. Accessed on 02/06/20

4. CDC Atlanta, available online at website https://www.cdc.gov/coronavirus/2019-ncov/prevent-gettingsick/prevention.html accessed on 03/06/20

5. Yatharth Sandesh, published online, 12 Aug, 2017(Hindi) Ancient Bhartiya Culture, available online at https://www.yatharthsandesh.com/blog/detailsnw/361. Accessed on $19 / 05 / 20$

6. Ministry of Health \& FW, Government of India, Consolidated Travel Advisory for Novel Coronavirus Disease (COVID-19)

7. Yogasutra of Patanjali, available online at https://patanjaliyogasutra.in/article/patanjali-yog-sutra/ accessed on $20 / 05 / 20$
Isha foundations Patanjali yogasutra. Available online at https://isha.sadhguru.org/in/en/wisdom/article/patanjali-yogasutras-true-nature. accessed on 20/05/20

9. The Concept of Shaucha or Cleanliness in Hindu Dharma. March 23, 2020. Nithin Sridhar. Available online at https://www.cisindus.org/2020/03/23/the-concept-of-shauchaor-cleanliness-in-hindu-dharma/ accessed on 19/05/20

10. Learning-Living manu smriti 10.63 : dharma in summary available online at http://www.learning-living.com/2017/11/manu-smriti1063-dharma-in-summary.html accessed on 20/05/20

11. Manusmriti the Laws of Manu - Introduction accessed online at https://www.hinduwebsite.com/sacredscripts/hinduism/dharma/ manusmriti.asp accessed on 18/05/20

12. Bihar Yoga official website available at https://www.biharyoga.net/ accessed on 21/05/20

13. Yoga for Health , accessed online at https://medlineplus.gov/ency/patientinstructions/000876.htm accessed on 18/05/20

14. Ayurveda: A Brief Introduction and Guide available online at https://www.ayurveda.com/resources/articles/ayurveda-a-briefintroduction-and-guide accessed on 22/05/20

15. Ayurveda's immunity boosting measures for self-care during COVID 19 crisis. Ministry of AYUSH available at https://main.ayush.gov.in/about-us/about-the-ministry accessed on $25 / 05 / 20$

16. Ministry of Culture, Government of India official website page, available online at https://www.indiaculture.nic.in accessed on $21 / 05 / 20$

17. Social Distancing. Keep Your Distance to Slow the Spread. CDC Atlanta. Available online at https://www.cdc.gov/coronavirus/2019-ncov/prevent-gettingsick/social-distancing.html accessed on 23/05/20

18. What is the Caste System in India? Accessed online from https://www.worldatlas.com/articles/the-caste-system-ofindia.html accessed on 29/05/20

19. The caste system. Ancient civilizations. Available online at https://www.ushistory.org/civ/8b.asp. accessed on 30/05/20

20. What is India's caste system? Available online at official website of BBC news. https://www.bbc.com/news/world-asia-india35650616. accessed on 21/05/20

21. The caste system image, adapted from. https://www.dw.com/en/indias-caste-system-weakened-but-stillinfluential/a-39718124 accessed on 23/05/20

22. Sanatan-Dharma (Hinduism) is the Best Religion to Stop Coronavirus. Available online at. https://eternalreligion.org/sanatan-dharma-hinduism-is-the-bestreligion-to-stop-coronovirus/ accessed on 25/05/20

23. CDC Atlanta USA. Cover your mouth and nose with a cloth face cover when around others. How to Protect Yourself \& Others. Coronavirus Disease 2019 (COVID-19) available online at https://www.cdc.gov/coronavirus/2019-ncov/prevent-gettingsick/prevention.html accessed on 25/05/20

24. Government of India. Advisory on use of Homemade Protective Cover for Face \& Mouth. Issued by the Office of the Principal Scientific Advisor to the Government of India_April 3, 2020

25. CDC Atlanta. Use of Cloth Face Coverings to Help Slow the Spread of COVID-19. Coronavirus Disease 2019 (COVID-19). Available at https://www.cdc.gov/coronavirus/2019-ncov/prevent-gettingsick/diy-cloth-face-coverings.html accessed on 25/05/20

26. What Indians Ate in the 12th Century. LHI Team available at https://www.livehistoryindia.com/snapshorthistories/2018/11/30/what-indians-ate-in-the-12th-century accessed on $25 / 05 / 20$

27. Bhaktivedanta database available online at https://vedabase.io/en/library/bg/17/8/ accessed on 25/05/20

28. Amanda Morris. Vitamin D Levels Appear to Play Role in COVID-19 Mortality Rates. May 7, 2020 // https://www.mccormick.northwestern.edu/news/articles/2020/0 5/vitamin-d-levels-appear-to-play-role-in-covid-19-mortalityrates.html accessed on 29/05/20 
29. Petre Cristian Ilie, Simina Stefanescu, Lee Smith. The role of Vitamin D in the prevention of Coronavirus Disease 2019 infection and mortality. DOI:10.21203/rs.3.rs-21211/v1accesssed online at https://www.researchsquare.com/article/rs-21211/v1 accessed on 30/05/20

30. Nair R, Maseeh A. Vitamin D: The "sunshine" vitamin. J Pharmacol Pharmacother. 2012;3(2):118-126. doi:10.4103/0976-500X.95506
31.

COMMUNITY//October 25, 2018, Sanatan Dharma- The Way of Living, India's gift to the world By Nikhil Chandwani, Nikhil Chandwan https://thriveglobal.com/stories/sanatan-dharma-theway-of-living/ accessed on 29/05/20

32. Cultures of India. Indian Culture And Traditions accessed online at https://goaman.weebly.com/ accessed on 29/05/20

\section{Tables}

TABLE 1 SUMMARY OF PERSONAL HYGIENE MEASURES AND OTHER PRECAUTIONARY MEASURES ADVISED BY MINISTRY OF HEALTH AND FAMILY WELFARE, GOVT. OF INDIA

\begin{tabular}{|l|l|}
\hline 1 & Frequent hand washing with soap \\
\hline 3 & $\begin{array}{l}\text { Following respiratory etiquettes - cover your mouth when coughing or sneezing with tissue or your own elbow. } \\
\text { Discard the tissue immediately in a closed bin. }\end{array}$ \\
\hline 4 & Do not touch your eyes, mouth and nose. Avoid touching as much as you can \\
\hline 5 & $\begin{array}{l}\text { Maintain Social distance of } 6 \text { feet (do gaz), } 2 \text { metre at all times. In market, shop, hospital even home as much as } \\
\text { possible. }\end{array}$ \\
\hline 6 & $\begin{array}{l}\text { Avoid close contact with people who are unwell or showing symptoms of illness, such as cough, runny nose etc. or } \\
\text { even you are having such symptoms. }\end{array}$ \\
\hline 7 & Avoid shaking hands as a greeting. \\
\hline 8 & Avoid contact with elderly people as they are more vulnerable \\
\hline 9 & Avoid contact with live animals and consumption of raw/undercooked meats \\
\hline 10 & Avoid travel to farms, live animal markets or where animals are slaughtered \\
\hline 11 & $\begin{array}{l}\text { Wear a mask if you have respiratory symptoms such as cough or runny nose. Now it is mandatory to wear mask (even } \\
\text { handmade) for coming out of your home. }\end{array}$ \\
\hline 12 & Avoid visitors at home or visit to others home. \\
\hline 13 & Follow the instructions being issued by the Government in Lockdown \\
\hline 14 & Utilise the AYUSH ministry guidelines for increasing immunity \\
\hline 15 & Adequate Vitamin D to boost Immunity \\
\hline 16 & Follow the guidelines for disposal of dead bodies. \\
\hline
\end{tabular}

\section{TABLE 2 AYUSH SELF-CARE GUIDELINES FOR PREVENTIVE HEALTH MEASURES AND BOOSTING IMMUNITY}

1 Drink warm water throughout the day

2 Yogasana, Pranayam \& Meditation for $30 \mathrm{~min}$

3 Spices like Haldi (Turmeric), Jeera (Cumin), Dhaniya (Coriander) and Lahsun (Garlic) are recommended in cooking

4 Chyavanprash 10gm (1tsf) in the morning

5 Drink herbal tea / decoction (Kadha) made from Tulsi (Basil), Dalchini (Cinnamon), Kalimirch (Black pepper), Shunthi (Dry Ginger) and Munakka (Raisin) - once or twice a day.

6 Golden Milk- Half tea spoon Haldi (turmeric) powder in $150 \mathrm{ml}$ hot milk - once or twice a day.

7 Nasal application - Apply sesame oil / coconut oil or Ghee in both the nostrils (Pratimarsh Nasya) in morning and evening.

8 Oil pulling therapy- Take 1 table spoon sesame or coconut oil in mouth. Do not drink, Swish in the mouth for 2 to 3 minutes and spit it off followed by warm water rinse. This can be done once or twice a day

9 Steam inhalation with fresh Pudina (Mint) leaves or Ajwain (Caraway seeds) can be practiced once in a day.

10 Lavang (Clove) powder mixed with natural sugar / honey can be taken 2-3 times a day in case of cough or throat irritation. 


\section{Figures}

FIGURE 1 VARIOUS TRADITIONS AND CUSTOMS OF SANATAN SANSKRITI AND THEIR ROLE IN PREVENTING COVID 19

\begin{tabular}{|c|c|}
\hline $\begin{array}{c}\text { HYGEINE \& SANITATION } \\
\text { (Hand washing, Environmental hygiene) }\end{array}$ & $\begin{array}{l}\text { - The concept of cleanliness ("Shaucha" in Sanskrit) is propounded by } \\
\text { Sanatan Sanskriti as basic duty of everyone } \\
\text { - Stress on cleanliness of oneself \& environment. } \\
\text { - No Spitting in Public } \\
\text { - Removal of Shoes outside }\end{array}$ \\
\hline $\begin{array}{l}\text { YOGA \& AYURVEDA } \\
\text { (Asanas to clear organs, Natural } \\
\text { ingridients to boost immunity) }\end{array}$ & $\begin{array}{l}\text {-Yogasanas to promote mental, spiritual \& physical wellbeing } \\
\text { - Ayurveda means "The Science of Life" aims at Prevention } \\
\text {-AYUSH - Self-care guidelines for preventive health measures \& } \\
\text { Boosting immunity to fight COVID } 19\end{array}$ \\
\hline $\begin{array}{c}\text { NAMASKAR, } \\
\text { SOCIAL-DISTANCING, } \\
\text { GAMCHHA, SATVIK BHOJAN }\end{array}$ & $\begin{array}{l}\text { - Namaskar means "I bow to the divine in you", Indian way of greeting } \\
\text { with Social Distancing } \\
\text { - Indian Caste system based on Occupational Hazards similar to social } \\
\text { distancing } \\
\text { - The all time Indian Mask - Gamchha } \\
\text { - Satvik Bhojan - Improves immunity and no risk of transmission from } \\
\text { the animal chain }\end{array}$ \\
\hline
\end{tabular}

\section{FIGURE 2 SOCIAL STRATIFICATION OF INDIAN CASTE SYSTEM, SOURCE GOOGLE IMAGES}

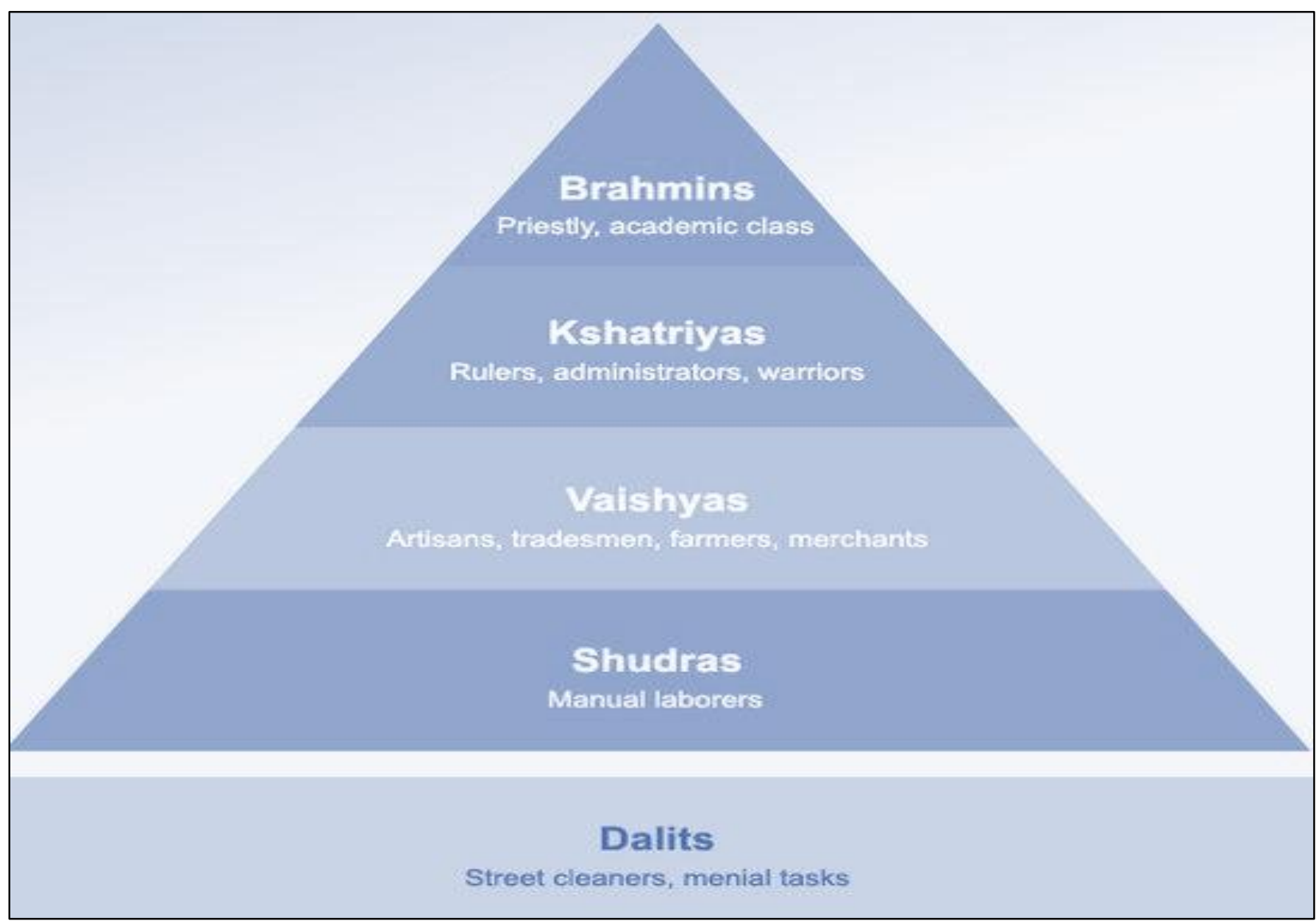

